THE EXCHANGE VALUE OF THE RENMINBI AND CHINA'S BALANCE OF TRADE: AN EMPIRICAL STUDY

Zhaoyong Zhang

Working Paper 5771

\author{
NATIONAL BUREAU OF ECONOMIC RESEARCH \\ 1050 Massachusetts Avenue \\ Cambridge, MA 02138 \\ September 1996
}

This paper was presented at the NBER East Asian Seminar on Economics, June 19-22, 1996. This work is part of the NBER's project on International Capital Flows which receives support from the Centre for International Political Economy. The author wishes to thank Anne Krueger, Takatoshi Ito, Larry Qiu, Kuo-liang Wang, Stanley Black and other participants of the conference for valuable comments and suggestions. Any opinions expressed are those of the author and not those of the National Bureau of Economic Research.

(C) 1996 by Zhaoyong Zhang. All rights reserved. Short sections of text, not to exceed two paragraphs, may be quoted without explicit permission provided that full credit, including $\mathbb{C}$ notice, is given to the source. 


\title{
THE EXCHANGE VALUE OF THE \\ RENMINBI AND CHINA'S BALANCE \\ OF TRADE: AN EMPIRICAL STUDY
}

\begin{abstract}
This paper aims at assessing the relationship between the exchange value of the Chinese Renminbi (RMG) and China's trade balance by means of some recent econometric techniques designed to evaluate the existence and the direction of causality. We find strong evidence suggesting that changes in the trade balance and each of its components Granger-cause changes in the exchange rate but no evidence indicating a causal link running from the exchange rate to the trade balance. Our results seem to be rather supportive of the accommodative role of the exchange rate proposed by the modern theory of the trade balance determination and not supportive of the existence of a Jcurve in China's trade balance. Our finding of a bidirectional causal relationship between the real exchange rate and the price variables confirms the presence of a vicious circle hypothesis following currency devaluation. This has important implications for the discussions of impacts of the RMB devaluation on China's trade balance.
\end{abstract}

\section{Zhaoyong Zhang}

Department of Economics and Statistics

National University of Singapore

10 Kent Ridge Crescent

SINGAPORE 119260

ecszzy@leonis.nus.sg 


\title{
THE EXCHANGE VALUE OF THE RENMINBI AND CHINA'S \\ BALANCE OF TRADE: AN EMPIRICAL STUDY
}

\author{
Zhaoyong Zhang
}

National University of Singapore

\section{Introduction}

In comparison with the transitional economies of Eastern Europe, China's experience of economic reforms is to some extent unique in that its economy, instead of sharp decline, grew rapidly in the context of the reform process that transformed the economy from a rigid central-planning system to an increasingly open and market-oriented economy. Equally remarkable, started in 1978, China has successfully broken through the state monopoly of foreign trade by decentralizing management power from state corporations and introduced the responsibility system or agency system into various levels of foreign trade institutions. On the other hand, the portion of foreign trade under direct administrative controls has been substantially reduced while more subject to the market forces. By 1991 exports and imports subject to mandatory planning had fallen to 30 percent and 20 percent of their respective totals, while the guidance plan accounted for 15 percent and 20 percent, respectively. As the role of trade plan has declined, direct control over exports and imports has continued through a licensing system which covered 55 percent of exports and 40 percent of imports in 1991 (Bell et al., 1993).

In line with its foreign trade system reform, China has repeatedly devalued its currency 
as a means of promoting exports and the balance of trade in the 1980s and the early 1990s. In 1991, China altered its foreign exchange policy from the relatively large, one-step currency devaluation of the past to more frequent, small-scale adjustments as ways of fine tuning the Renminbi's (RMB) value according to prevailing conditions. The unification of China's two main currency rates in the beginning of 1994 and the deregulation on foreign invested enterprises in exchanging funds freely at selected banks without approval from the State Administration for Exchange Control (SAEC) early this year drive the RMB a step further toward the full convertibility. China's foreign exchange system has been, since the mid-1980s, classified as a more flexible management system. ${ }^{1}$

In this paper we shed light on the relationship between the exchange value of the RMB and China's trade balance by means of some recent econometric techniques designed to evaluate the existence and the direction of causality. This will generate some important implications as to the discussions of impacts of RMB devaluation on China's trade balance. We follow an empirical methodology applied by Mahdavi and Sohrabian (1993) to test for causality in the relationships between the nominal and real exchange rates of the RMB and China's balance of trade as well as its price and quantity components over the period 1991:M01-1996:M02.

This paper is organized as follows. In section 2 we briefly review the major changes of China's foreign exchange policy. Section 3 is devoted to the empirical methodology and the theories to explain the relation between exchange rate and trade balance. Section 4 describes the data and the empirical results, and the final section wraps up the analysis with some concluding remarks.

${ }^{1}$ Since 1987 the exchange rate of RMB has been formally classified by IMF as a more flexible arrangement (other managed float). 


\section{Foreign Exchange Policy: An Overview}

The pre-reform exchange system of China was characterized by strict control of foreign exchange transactions and rigidity of the RMB exchange rate. It could neither respond flexibly to the change of price parities between China and the rest of the world, nor make prompt adjustment according to the changing supply and demand of foreign exchange. At most, it acted as an accounting tool, and failed to adjust the trade volume. This is actually associated with the state monopoly of China's foreign trade regime under which all import and export contracts with foreign firms could only be signed by a few authorized import and export corporations. ${ }^{2}$ Conspicuously, traders under this regime had no incentives to make trade adjustments in response to prices changes and exchange rate policy.

During the early stages of the reform, various arrangements were tested for sharing foreign exchange with the objective of improving incentives for exports. A retention system emerged, under which exporters surrender their actual foreign exchange earnings and are issued retention quotas by the SAEC equivalent to a portion of such earnings. This system has evolved with a complex set of regulations on allocating foreign exchange according to industry and location before a uniform retention rate for enterprises was set throughout the country by $1991 .^{3}$ Other measures to promoting exports include various export subsidies ${ }^{4}$ and

${ }^{2}$ The number of the specialized foreign trade corporation had risen and fallen over the entire pre-reform period, partly due to the structural changes of the administrative ministries. By 1978, only 10 national import and export corporations under China's trade ministry had been solely authorized to sign import and export contracts with foreign firms.

${ }^{3}$ The new rules announced in February 1991 allows exporters (other than foreign-funded enterprises) to receive retention quotas for 80 percent of their foreign exchange earnings, while 100 percent for mechanical and electronical products. These retention quotas are distributed to foreign trade corporation (60 percentage points), the supplying enterprises (10 percentage points), and the local government (10 percentage points). The practice of the foreign exchange retention system has been terminated in 1992 due to considerable distortions 
decentralization of decision-making to the trading units or foreign trade corporations which had soared to more than 6000 in existence by 1989 (World Bank, 1990). The introduction of the responsibility system or agency system into various levels of foreign trade institutions in the mid-1980s further increased the freedom of these economic agents in response to the market forces in managing international trade. The foreign trade system reform has no doubt contributed to the rapid expansion of China's foreign trade. In 1978 the total trade amounted only to US $\$ 20.6$ billion and it rose to US\$165.5 billion in 1992 , an increase of over eight times. Exports grew at a similar pace, rising from US\$9.75 billion in 1978 to US\$84.9 billion in 1992 (Zhang, 1995).

In 1981 China introduced a dual exchange rate system: one is for non-trade transactions at a rate of about RMB 1.5 yuan per dollar; and another rate is more favourable for the internal settlement of trade transactions. The dual rate system was abandoned in 1985 but re-emerged in 1986 with the establishment of the foreign exchange adjustment centres (FEACs) or swap centres at which approved enterprises were permitted to buy and sell retention quotas. After freer trading was permitted in 1988, the premium on exchange rates in the swap centres rose to about 80 percent, reflecting an increased number of participants at the same time as aggregate demand was surging. The swap markets had come to dominate China's foreign-currency transactions, representing an estimated 80-85 percent of all such activity at over 100 swap locations. The exchange rate at the swap centres had been set by a combination of market forces and government intervention, although such interventions were

and unfair regional competition.

${ }^{4}$ The practice of export subsidies to foreign trade corporations was abolished in 1991 when China deepened its foreign trade system reform in the early 1990s, focusing on increasing the transparency of the system and moving closer to the international conventions in conducting trade. 
rare. In 1989, the premium fell sharply in the wake of a devaluation of the official exchange rate, and thereafter the differential between the two rates narrowed to about 8 percent before it widened again to about 45 percent by early 1993 (Bell et al. 1993). This depreciation occurred against the background of strong import growth stemming from rapid economic growth, an investment boom, and trade liberalization initiatives. Figure 1 displays the movements of both nominal and real exchange rates during the reform period.

With the more flexible exchange arrangements in 1986, the official exchange rate was in effect pegged to the US dollar. In 1991, the exchange policy was altered to small-scale, more frequent adjustments in the official rate according to the prevailing conditions from the relatively large, one-step currency devaluations of the past, following the two currency devaluations in 1989 (21 percent) and 1990 (9 percent). The new policy kicked off with a devaluation of 0.95 percent on April 9, 1991 to RMB 5.2935 per dollar, and another on May 20, bring the value to RMB 5.3066 per dollar. Several additional small adjustments were made throughout the year, taking the value to around RMB 5.4 per dollar by the end of 1991 . By April 1993, the real effective exchange rate of the official exchange rate had depreciated 33 percent more than in 1986 and 70 percent more than in 1980 (Bell et al. 1993). One key reason for those continuous currency devaluation is to reduce the price distortion and promote exports. This seems to be true in some sense that there did exist certain relationship between exchange rate and trade flows in the 1980s..$^{5}$ One must note however that the Chinese authority has been very cautiously to devalue its highly over-valued currency over time. It is mainly due to the consideration of the inflationary effect of currency devaluation.

${ }^{5}$ Wang (1993) find that there is a positive relationship between real exchange rate and exports. Using quarterly data for 1980:I to 1989:IV, Brada, Kutan and Zhou (1993) find that, in both the short-run and the long-run, devaluation of the RMB serves to improve the balance of trade. 
Figure 1a: Nominal Exchange Rates of the RMB

(1979-1996)

Yuan per U.S. Dollar

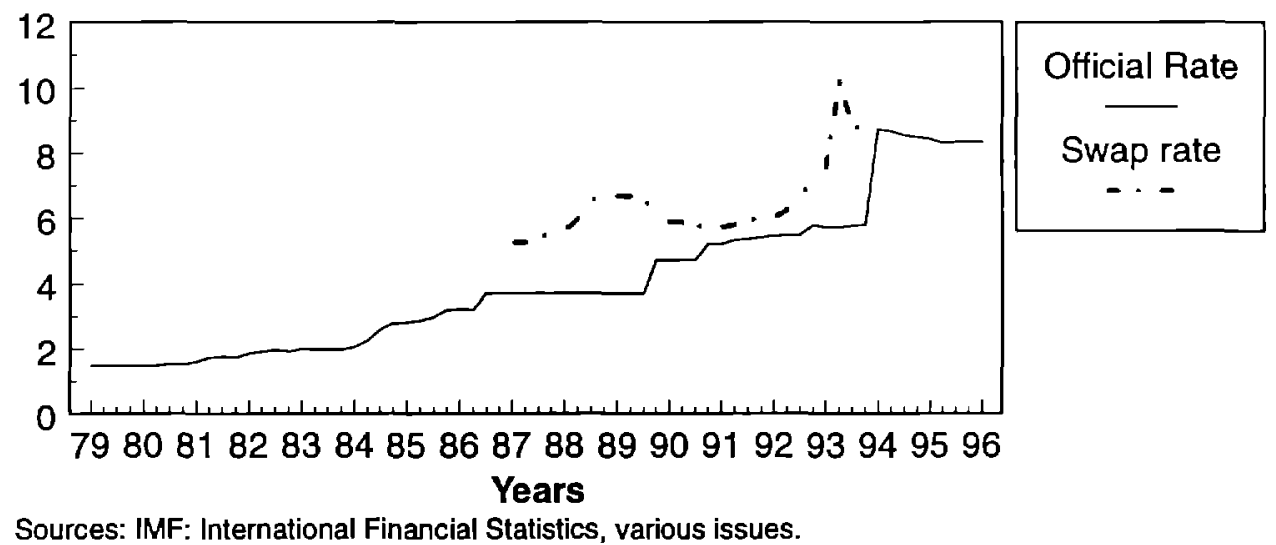

Sources: IMF: International Financial Statistics, various issues.

Figure 1b: Real Exchange Rates of the RMB

(1979-1996)

Yuan per U.S. Dollar

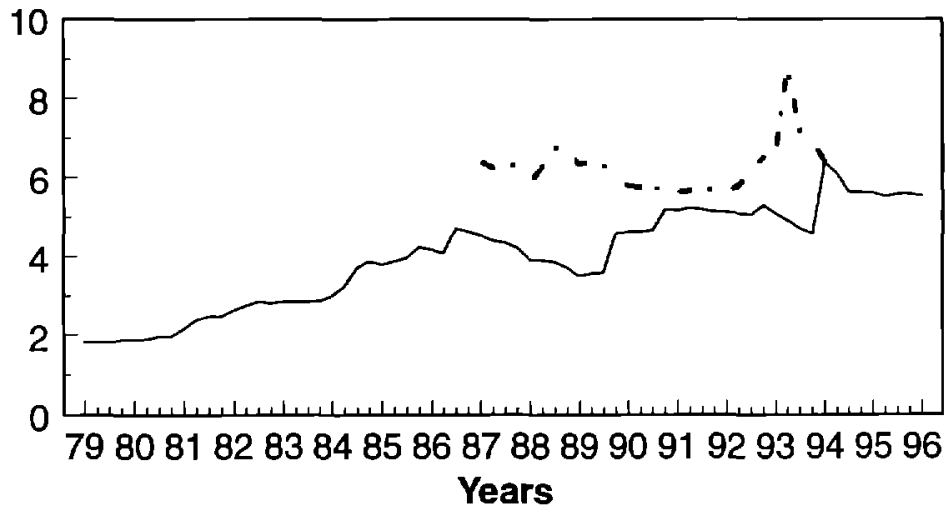

Official Rate

Swap rate

- -

Sources: IMF: International Financial Statistics, various issues. 
One notable step in the foreign exchange reform was the unification of China's two main currency rates (the swap rates and the official rates) and allowed the exchange rate limited room to freely float from the beginning of 1994 . This led to a substantial devaluation of the currency to RMB 8.7 yuan to the dollar, a rate quite close to that in the black market. Since then the exchange value of the RMB has been remained stable, while appreciated against the US dollar in the last two years by about 5 percent in nominal terms and 22 percent in real terms. As a matter of fact, China's exports during this period grew rapidly by 24 percent in 1994 and 23 percent in 1995 with a trade surplus of US\$5.1 billion and US $\$ 16.7$ billion, respectively. This raised a question over the relationship between the real exchange rate and the balance of trade in the transitional economy of China. However, it has no doubt that the exchange rate in the Chinese economy plays a major role in the level and composition of exports and imports (World Bank, 1990).

Since March 1996, restrictions on the foreign exchange transfers of foreign invested firms in 4 cities (Shanghai, Shenzhen, Dalian and Jiangsu) have been removed such that they could exchange funds freely at selected banks without approval from the SAEC. This program is expected to be extended to the rest of the country and also granted to the local firms soon. The ultimate goal of the reform is convertibility of the currency and integration of the economy with international currency market. Although full RMB convertibility is less likely achieved by the end of the century, current account convertibility could be a reality as early as next year.

\section{The Theoretical Framework and Methodology}

There are mainly two competing theories put forward to explain the relation between 
exchange rate and trade balance. The first one is based on "the J-curve hypothesis" according to which, following a devaluation of the nominal exchange rate, the nominal trade balance initially deteriorates before it improves. The empirical results of some recent studies do not provide a clear-cut answer regarding the validity of the J-curve hypothesis. Rosenswieg and Koch (1988), Mead (1988), and Mahdavi and Sohrabian (1993) find evidence of a "delayed J-curve pattern" consisting of a number of overlapping standard J-curve. Some others even find no statistically reliable evidence of a stable J-curve (Rose and Yellen, 1989). The central points of these studies seem to suggest a slow and partial pass-through of changes in the exchange rate into import prices and even a relatively quicker and larger pass-through into export prices.

The second theory to explaining the relation between exchange rate and trade balance is the so-called "modern theory" of trade balance determination (Greenwood, 1984; Razin, 1984; McKinnon and Ohno, 1986). This theory gives great weight to intertemporal shocks and exogenous supply shocks in explaining trade imbalances. The empirical consequences of this modern theory are twofold: first, because exogenous factors affect the movements of both the real exchange rate and the trade balance, the change in one variable can only partially explain the change in the other variable; second, the relationship between the two variables may be bidirectional (Hill, 1990). However, empirical studies of the nexus between real exchange rate and the trade balance have usually assumed a unidirectional causal relationship in the opposite direction (Himarios, 1989).

The theoretical discussion of the J-curve hypothesis can be better described by the following equation: ${ }^{6}$

\footnotetext{
${ }^{6}$ For the discussion of a J-curve effect following devaluation, see Melvin (1985), and Mahdavi and Sohrabian (1993).
} 


$$
B O T=P X \cdot Q X-P M \cdot Q M
$$

where BOT is the trade balance in local currency, PX is unit price of exports, QX is volume of exports, PM is unit price of imports, and QM is volume of imports. Assume that the economy's export and import contracts are mainly written in local currency and dollars, respectively. A devaluation of the exchange rate will raise the imports value of the economy in local currency due to the rising of import price, while the export value will remain unchanged. In the short run, the trade balance will be deteriorated. Over a longer period of time, the export and import volumes will react to the changes in the relative prices following the devaluation. Downward adjustment in import volume is expected while export volume will rise as the export prices expressed in dollars become more competitive. This will result in an improvement in the trade balance. Thus, a devaluation of the exchange rate will affect the trade balance through both price effect and volume effect, the former effect of the devaluation leads to the deterioration of the trade balance, i.e. the declining segment of the J-curve, while the latter effect contributes to the improvement of trade balance, i.e. the rising part of the Jcurve. In this study, we attempt to examine the dynamic relationship between the exchange rate and the trade balance as well as the nature and direction of causal relationship between the exchange rate and the price and quantity components of the trade balance. The existence of certain dynamic links between these variables may provide explanatory evidence to the understanding of how the trade balance responds to the changes in the exchange rate.

Testing for causality between variables in the Granger sense of the world implies the specification of the dynamic relationships which link them. In order to correctly specify these dynamic relationships, one needs first examine the behaviour of each variable over time to determine whether it is stationary. Failure to do so can lead to a problem of spurious regression whereby the results suggest that there are statistically significant long-run 
relationships between the variables in the regression model when in fact all that is being obtained is evidence of contemporaneous correlations rather than meaningful causal relations. If non-stationary variables are found, then one needs to find out whether they are cointegrated in order to infer a causal long-run relationship between non-stationary time series.

We have therefore investigated the dynamic properties of the time series of the variables, firstly if they are stationary in levels or in differences, by means of the well-known "augmented Dickey-Fuller test" (ADF) (Dickey and Fuller, 1981). If stationarity for a time series is achieved with d times of differences, then it is said to be integrated of order d or $\mathrm{I}(d)$. To test whether a time series, $X_{t}$, is nonstationary ( or contains a unit root), we set the following regression model:

$$
\Delta X_{t}=\alpha+\beta_{0} X_{t-1}+\sum_{i=1}^{n} \beta_{i} \Delta X_{t-i}+\gamma T r+\mu_{t}
$$

where $\operatorname{Tr}$ is a time trend, and $\mu$ is an error term. The null hypothesis that $X_{t}$ contains a unit root is set at $H_{0}: \beta_{0}=0$, against the alternative $H_{j}: \beta_{0}<0$. The null hypothesis is rejected if $\beta_{0}$ is significantly negative. Even though each individual variable is found to have a unit root, it is still possible to infer a causal long-run relationship(s) between non-stationary variables if they are cointegrated.

We use two methods to examine if the exchange rate and the trade balance as well as its component variables are cointegrated. The first method uses the Engle-Granger two-step approach in which the first step tests whether each of the variables of interest has a stochastic trend and then tests whether stochastic trends in these variables are related by examining if the residual of the cointegrating regression has a unit root or not. If the residual does not have a unit root, then the variables of interest are cointegrated (Engle and Granger, 1987). However, despite its popularity, there are other serious problem with the Engle-Granger 
approach such as small sample bias and the inability to test statistical hypotheses. The second method employed to test for cointegration is the maximum likelihood (ML) method provided by Johansen (1988, 1992) and Johansen and Juselius (1990), which is more efficient and powerful in estimating and testing the cointegrating vectors in a multivariate setting.

The Johansen method to test for cointegration is based upon a vector error-correction (VECM) system with a Gaussian error term:

$$
\Delta Z_{t}=\alpha_{0}+\Pi Z_{t-p}+\sum_{i=1}^{p-1} \theta_{i} \Delta Z_{t-i}+\omega_{t} \quad(t=1, \ldots, T)
$$

where $Z_{t}$ is a column vector of $m$ endogenous variables, $\Pi$ and $\theta$ are $m$ by matrices of unknown parameters, and $\omega_{t}$ is a Gaussian error term. All long-run information about the relationship between variables is contained in the impact matrix $\Pi$. When the matrix $\Pi$ has full column rank, it implies that all variables in $Z_{t}$ are stationary. When the matrix $\Pi$ has zero rank, the system is a traditional first-differenced VAR involving no long-run elements. However, when the rank of $\Pi$ is intermediate or $0<\operatorname{rank}(\Pi)=r<m$, there exist $r$ cointegrating vectors that make the linear combinations of $Z_{t}$ become stationary or cointegrated. In this case, $\Pi$ can be decomposed into two $m$ by $r$ matrices, $\Phi$ and $\Omega$, such that the reduced rank $r<m$ of $\Pi$ is hypothesized as $H(r): \Pi=-\Phi \Omega^{\prime}$. The vectors of $\Omega$ represent the $r$ linear cointegrating relationships such that $\Omega^{\prime} Z_{t}$ is stationary. The matrix $\Phi$ represents the error-correction parameters. The ML estimation procedure provides an likelihood ratio (LR) test called trace test that evaluates the null hypothesis of, at most, $r$ cointegrating vectors versus the general null of $m$ cointegrating vectors. Another test derived by Johansen (1988) is the maximum eigenvalue test which is a more powerful LR test. This test is to evaluate the null hypothesis of $r$ cointegrating vectors against the alternative of $(r+1)$ cointegrating vectors. Rejection of this hypothesis suggests the existence of the maximum $r$ cointegrating 
vectors.

Finally, to test for causality between two variables, $X_{t}$ and $Y_{t}$, we follow the classical procedures of Granger $(1969,1986)$ and Engle and Granger (1987). The methodology differs whether the variables are cointegrated or not. If $X_{t}$ and $Y_{t}$ are not cointegrated, then the standard Granger-causality tests is used to examine the causal relationships between them. This test is based on the estimation of the following dynamic relationships between the variables (if individually I(1) processes):

$$
\begin{aligned}
& \Delta X_{t}=\kappa_{0}+\sum_{i=1}^{m} \delta_{i} \Delta X_{t-i}+\sum_{j=1}^{n} \rho_{j} \Delta Y_{t-j}+v_{1 t} \\
& \Delta Y_{t}=\eta_{0}+\sum_{i=1}^{p} \phi_{i} \Delta Y_{t-i}+\sum_{j=1}^{q} \psi_{j} X_{t-j}+v_{2 t}
\end{aligned}
$$

where $\left(v_{l t}, v_{2 t}\right)$ is a serially independent random vector with zero mean and finite covariance matrix. To ascertain the presence of unidirectional, bidirectional or no causal relationships between variables of interest, we can test the joint significance of coefficients of the causal variables in each equation by means of a classical F-test.

However, if the two time series appear to be cointegrated, causality has to be investigated within the framework of an error correction model (ECM) which incorporates the information provided by cointegrating relationships into causality analysis that usually focuses on short-term dynamics. The ECM is given by the following form (if individually I(1) processes):

$$
\Delta X_{t}=\kappa_{0}+\sum_{i=1}^{m} \delta_{i} \Delta X_{t-i}+\sum_{j=1}^{n} \rho_{j} \Delta Y_{t-j}+\lambda_{1} \varepsilon_{1 t-1}+v_{1 t}
$$

where $\varepsilon_{l t-I}$ is the lagged value of estimated $\varepsilon_{t}$ from the cointegrating regressions of $X_{t}$ and $Y_{t}$ with a constant term. Note that $\lambda_{1}$ is the error-correction coefficient. Even if the first 
differences of $Y_{t}$ regressor do not enter the above equation, the lagged level of $Y_{t}$ might still Granger-cause the variable $X_{t}$ through the residual. The existence of one cointegrating relationship between the two variables ensure there exists at least one causality link (in the Granger sense) between them. A statistically significant $\lambda_{1}$ indicates such a causal link even when the coefficients of lagged changes of the causal variables are jointly insignificant (implying no causality according to the standard Granger-causality tests) (Miller and Russek, 1990).

\section{Data and Empirical results}

\subsection{Data}

The methodology described in the last section is employed to investigate the dynamic relationships between the exchange value of Chinese RMB and China's trade balance as well as its price and quantity components. The period under investigation ranges from January 1991 to February 1996, a more flexible, relatively floating rate era. This period witnessed the rapid expansion of China's foreign trade and FDI flows. Besides data availability, one key reason to limit our tests to this period is that this period covers the most notable events in the process of China's foreign trade system reform. These include for instance the abolition of export subsidies in 1991 and of the foreign exchange retention system in 1992, and the unification of its dual foreign exchange system in 1994. Following the implementation of deep structural reforms, it is more evidenced that China has begun to conduct its foreign trade in accordance with its comparative advantage and the international conventions rather than the use of administrative measures. Therefore, it will be more interesting to evaluate if the new 
foreign trade regime can make the balance of trade response to the exchange rate, in other words, if the devaluation of the Chinese currency improves the balance of trade. The major sources of data are IMF: International Financial Statistics, the Statistical Yearbook of China, the Monthly Statistics of China, and Hong Kong Monthly Digest of Statistics. The variables involved in the analysis are measured as follows:

BOTN: nominal trade balance defined as the difference between the nominal values of exports and imports.

BOTR: real trade balance defined as the nominal trade balance deflatored by the China's consumer price index.

EXCHN: nominal exchange value of the RMB as measured by the trade-weighted exchange rate index of the RMB against the four countries (Hong Kong, Japan, Singapore, and the United States) as they are the largest trading partners of China, taking a share of 60 percent in China's total foreign trade. Their average shares in China's foreign trade from 1991 to 1996 were used as weights in calculating the index.

EXCHR: real exchange rate defined as the nominal rate of RMB multiplied by the relative price ratio of the world price level over that of China. The consumer price indexes are used. The index of the world price level is taken to be the trade-weighted consumer price index of the four countries.

PX and PM: China's export and import prices, respectively, as measured by export (import)-weighted unit value of import and export indexes of China's four largest trading partners.

QX and QM: export and import volumes, respectively, calculated by dividing the values of exports and imports by the corresponding unit value index. 


\subsection{Testing for Unit Roots}

The results of the ADF test for the eight variables are presented in Table 1. They support the presence of a unit root in all of the series, while stationarity is achieved after first differencing of the levels for trade balance and the volume of exports and imports, and after the second differencing of the levels of exchange rate and export and import prices. These results are particularly important in order to avoid spurious regression problems as observed in many earlier studies of the exchange rate and trade balance nexus. They are also important to the understanding of those controversial issues regarding the RMB devaluation and its impact on China's trade balance, as studies based on the conventional method without taking unit root into account will generate divergent, even opposite conclusion as those taking some transformation (e.g., first-differencing) before stationarity is achieved. ${ }^{7}$

Table 1: Augmented Dickey-Fuller Test for the Presence of Unit Roots (1991:M01-1996:M02)

\begin{tabular}{||l|c|l|c||}
\hline Variables & ADF lag length & 1st difference & 2nd difference \\
\hline BOTN & $\operatorname{ADF}(1)$ & $-0.6647(-3.559)^{* *}$ & --- \\
BOTR & $\operatorname{ADF}(1)$ & $-0.5840(-3.748)^{* *}$ & --- \\
EXCHN & $\operatorname{ADF}(3)$ & $-0.1783(-2.114)$ & $-1.1368(-3.848)^{* *}$ \\
EXCHR & $\operatorname{ADF}(1)$ & $-0.1423(-1.320)$ & $-1.1594(-6.189)^{* *}$ \\
PM & $\operatorname{ADF}(1)$ & $-0.0810(-2.078)$ & $-0.7206(-4.526)^{* *}$ \\
PX & $\operatorname{ADF}(2)$ & $-0.0630(-1.464)$ & $-0.7011(-3.693)^{* *}$ \\
QM & $\operatorname{ADF}(1)$ & $-1.5208(-7.543)^{* *}$ & --- \\
QX & $\operatorname{ADF}(1)$ & $-1.1769(-5.952)^{* *}$ & --- \\
\hline
\end{tabular}

Note: The $t$-statistics are in the parentheses. At the usual 5 percent level of significance, the critical values for rejecting the null hypothesis are equal to -2.93 and -2.89 for 50 and 100 observations, respectively, (Fuller, 1976). ${ }^{* *}$ means significantly negative at the 5 percent level.

${ }^{7}$ For instance, Rose and Yellen (1989) find little or no evidence of the existence of a Jcurve in the U.S. trade balance, while the use of data in levels would have led to an opposite result. 


\subsection{Testing for Cointegration}

Testing for cointegration is carried out by employing both the Engle-Granger approach and the Johansen procedure. For the Engle-Granger procedure, the levels and changes of all of the variables have been used. The ADF tests are applied for detecting a unit root in the residuals of the relevant cointegrating regressions, which involves regressing the following equations:

$$
\Delta \varepsilon_{t}=d_{0}+d_{1} \varepsilon_{t-1}+\sum_{i=1}^{n} d_{i} \Delta \varepsilon_{t-i}+\tau_{t}
$$

where $\varepsilon$ is the residual from the cointegrating regression. These unit root tests show that while the residuals from the regressions of the levels of the variables have unit roots, those from the first difference regressions do not (Table 2 and 3). These results are consistent with the inference that while levels of exchange rate and trade balance as well as its components are not cointegrated, changes of these variables are cointegrated, implying the presence of a longrun stable linear relationship between exchange rate and trade balance and its components.

Table 4 displays the results of the Johansen procedure used to test for cointegration. With only a few exceptions, the Johansen procedure yields a quite similar result as the EngleGranger method, implying the presence of a long-run stable linear relationship between the (real) exchange rate and the (real) trade balance and its quantity components. The results also suggest a weak long run relationship between the (real) exchange rate and the export price but no long-run relationship between the exchange rate and the import price variable. Our findings contrast with those obtained in similar studies on OECD countries such as Rose and Yellen (1989), Mahdavi and Sohrabian (1993), and even Gruen and Wilkinson (1994). The latter find weak evidence of a stable relationship between the Australian real exchange rate 
and the terms of trade in 1969-1990.

Table 2: Cointegration Tests Based on the ADF Procedure in Nominal Measures

\begin{tabular}{||l|l|l|l|l|l||}
\hline \multicolumn{1}{|c|}{$\mathrm{X}_{\mathrm{t}}$} & \multicolumn{1}{|c|}{$\mathrm{Y}_{\mathrm{t}}$} & $\begin{array}{l}\text { ADF Test } \\
\text { Statistic }\end{array}$ & \multicolumn{1}{|c|}{$\Delta \mathrm{X}_{\mathrm{t}}$} & \multicolumn{1}{|c|}{$\Delta \mathrm{Y}_{\mathrm{t}}$} & \multicolumn{1}{|c|}{$\begin{array}{c}\text { ADF Test } \\
\text { Statistic }\end{array}$} \\
\hline BOTN & EXCHN & $-0.62(-3.08)$ & BOTN & EXCHN & $-1.97(-7.98)^{* *}$ \\
EXCHN & BOTN & $-0.04(-1.06)$ & EXCHN & BOTN & $-1.08(-5.12)^{* *}$ \\
PM & EXCHN & $-0.06(-1.29)$ & PM & EXCHN & $-0.72(-4.52)^{* *}$ \\
EXCHN & PM & $-0.05(-1.00)$ & EXCHN & PM & $-1.09(-5.78)^{* *}$ \\
PX & EXCHN & $-0.03(-0.67)$ & PX & EXCHN & $-0.91(-6.01)^{* *}$ \\
EXCHN & PX & $-0.03(-0.81)$ & EXCHN & PX & $-1.09(-5.79)^{* *}$ \\
QM & EXCHN & $-0.90(-3.32)$ & QM & EXCHN & $-2.10(-9.92)^{* *}$ \\
EXCHN & QM & $-0.28(-2.44)$ & EXCHN & QM & $-1.09(-5.81)^{* *}$ \\
QX & EXCHN & $-0.75(-3.17)$ & QX & EXCHN & $-2.54(-7.03)^{* *}$ \\
EXCHN & QX & $-0.26(-2.36)$ & EXCHN & QX & $-1.10(-5.83)^{* *}$ \\
\hline
\end{tabular}

Note: The $t$-statistics are in the parentheses. The 5 percent critical value for the $t$-statistic is 3.62; see Engle and Yoo (1987).

Table 3: Cointegration Tests Based on the ADF Procedure in Real Measures

\begin{tabular}{||l|l|l|l|l|l||}
\hline $\mathrm{X}_{\mathrm{t}}$ & \multicolumn{1}{|c|}{$\mathrm{Y}_{\mathrm{t}}$} & $\begin{array}{l}\text { ADF Test } \\
\text { Statistic }\end{array}$ & $\Delta \mathrm{X}_{\mathrm{t}}$ & \multicolumn{1}{|c||}{$\Delta \mathrm{Y}_{\mathrm{t}}$} & \multicolumn{1}{|c|}{$\begin{array}{l}\text { ADF Test } \\
\text { Statistic }\end{array}$} \\
\hline BOTR & EXCHR & $-0.47(-2.64)$ & BOTR & EXCHR & $-2.17(-6.34)^{* *}$ \\
EXCHR & BOTR & $-0.03(-0.72)$ & EXCHR & BOTR & $-1.14(-6.17)^{* *}$ \\
PM & EXCHR & $-0.03(-1.57)$ & PM & EXCHR & $-0.72(-4.52)^{* *}$ \\
EXCHR & PM & $-0.05(-0.99)$ & EXCHR & PM & $-1.16(-6.18)^{* *}$ \\
PX & EXCHR & $-0.05(-1.28)$ & PX & EXCHR & $-0.91(-6.02)^{* *}$ \\
EXCHR & PX & $-0.01(-0.13)$ & EXCHR & PX & $-1.16(-6.20)^{* *}$ \\
QM & EXCHR & $-0.68(-2.85)$ & QM & EXCHR & $-2.66(-7.79)^{* *}$ \\
EXCHR & QM & $-0.05(-0.40)$ & EXCHR & QM & $-1.16(-6.18)^{* *}$ \\
QX & EXCHR & $-0.80(-3.00)$ & QX & EXCHR & $-2.60(-7.39)^{* *}$ \\
EXCHR & QX & $-0.08(-0.58)$ & EXCHR & QX & $-1.17(-6.37)^{* *}$ \\
\hline
\end{tabular}

Note: The $t$-statistics are in the parentheses. The 5 percent critical value for the $t$-statistic is 3.62; see Engle and Yoo (1987). 
Table 4: Cointegration Tests Based on the Johansen Procedure

\begin{tabular}{|c|c|c|c|c|c|}
\hline \multirow[t]{2}{*}{ Variables } & \multirow[t]{2}{*}{ Lag length $^{a}$} & \multicolumn{2}{|c|}{ Hypothesis } & \multicolumn{2}{|c|}{ Test statistics } \\
\hline & & $\mathrm{H}_{0}$ & $\mathrm{H}_{\mathrm{I}}$ & Eigenvalue & Trace \\
\hline EXCHN-BOTN & $p=6$ & $\mathrm{r}=0$ & $r=1(r \geq 1)^{b}$ & $37.23 * * *$ & $31.50^{* * *}$ \\
\hline \multirow[t]{2}{*}{ EXCHN-PM } & \multirow[t]{2}{*}{$p=1$} & $\mathrm{r}=0$ & $r=1(r \geq 1)$ & 8.31 & 10.58 \\
\hline & & $r \leq 1$ & $r=2$ & 3.05 & 2.81 \\
\hline \multirow{2}{*}{ EXCHN-PX } & \multirow{2}{*}{$p=1$} & $\mathbf{r}=0$ & $r=1(r \geq 1)$ & 8.08 & 12.77 \\
\hline & & $r \leq 1$ & $r=2$ & 5.35 & 5.11 \\
\hline \multirow[t]{2}{*}{ EXCHN-QM } & \multirow[t]{2}{*}{$p=1$} & $r=0$ & $r=1(r \geq 1)$ & $44.15^{* * *}$ & $44.28 * * *$ \\
\hline & & $r \leq 1$ & $r=2$ & 4.87 & 4.40 \\
\hline \multirow[t]{2}{*}{ EXCHN-QX } & \multirow[t]{2}{*}{$p=1$} & $r=0$ & $r=1(r \geq 1)$ & $31.33 * * *$ & $33.24 * * *$ \\
\hline & & $r \leq 1$ & $\mathbf{r}=2$ & 5.47 & 4.94 \\
\hline \multirow[t]{2}{*}{ EXCHR-BOTR } & \multirow[t]{2}{*}{$p=6$} & $\mathbf{r}=0$ & $r=1(r \geq 1)$ & $20.09 * * *$ & $15.08^{*}$ \\
\hline & & $r \leq 1$ & $\mathbf{r}=2$ & 0.87 & 0.62 \\
\hline \multirow[t]{2}{*}{ EXCHR-PM } & \multirow[t]{2}{*}{$\mathrm{p}=1$} & $\mathrm{r}=0$ & $r=1(r \geq 1)$ & 9.13 & 11.87 \\
\hline & & $\mathrm{r} \leq 1$ & $\mathbf{r}=2$ & 3.15 & 3.04 \\
\hline \multirow[t]{2}{*}{ EXCHR-PX } & \multirow[t]{2}{*}{$\mathrm{P}=1$} & $r=0$ & $r=1(r \geq 1)$ & $14.07^{* *}$ & $18.03 * *$ \\
\hline & & $r \leq 1$ & $r=2$ & 4.89 & 4.68 \\
\hline \multirow[t]{2}{*}{ EXCHR-QM } & \multirow[t]{2}{*}{$\mathrm{p}=1$} & $r=0$ & $r=1(r \geq 1)$ & $45.44 * * *$ & $45.04 * * *$ \\
\hline & & $r \leq 1$ & $r=2$ & 2.81 & 2.63 \\
\hline \multirow[t]{2}{*}{ EXCHR-QX } & \multirow[t]{2}{*}{$\mathrm{p}=1$} & $r=0$ & $r=1(r \geq 1)$ & $29.62 * * *$ & $30.30 * * *$ \\
\hline & & $r \leq 1$ & $r=2$ & 2.84 & 2.65 \\
\hline
\end{tabular}

Notes: a. the lag length is determined by AIC.

b. $(r \leq 1)$ is the alternative for the test based on the trace of the stochastic matrix.

* Hypothesis of cointegration accepted at the $90 \%$ level.

** Hypothesis of cointegration accepted at the $95 \%$ level.

*** Hypothesis of cointegration accepted at the $99 \%$ level.

\subsection{Testing for Causality}

As the results of the Johansen test statistics do not seem to suggest that the real exchange rate of the RMB is cointegrated with the import price variable and the nominal exchange rate is cointegrated with import and export prices variables, the dynamic equations 
used for the purpose of the Granger-causality tests may be specified in the first-difference form according to the standard methodology such as equations 4 and 5 . As for the rest the results from both the Engle-Granger method and the Johansen procedure indicate that the exchange value of the RMB is cointegrated with the trade balance and its quantity components as well as the export price (for the real exchange rate), the causal links between these variables in the Granger sense can be specified in the first- and second-difference forms by including an error-correction term as in equations (6) and (8).

$$
\Delta^{2} X_{t}=\kappa_{1}+\sum_{i=1}^{m} \delta_{i} \Delta^{2} X_{t-i}+\sum_{j=1}^{n} \rho_{j} \Delta^{2} Y_{t-j}+\lambda_{2} \varepsilon_{2 t-1}+v_{2 t}
$$

where $\Delta^{2}$ is the second difference operator, and $\lambda_{2}$ is the error-correction coefficient. As stated earlier if $\Delta X$ and $\Delta Y$ are cointegrated then there should be Granger-causation in at least one direction, i.e. $\lambda \neq 0$. Hence, even if the second differences of $\mathrm{X}$ and $\mathrm{Y}$ regressors do not enter equation (8), first differences might through the residual and hence Granger-cause $\mathrm{Y}$ and/or $\mathrm{X}$ variables. The results of the Granger-causality procedure using nominal measures of the exchange rate and trade balance are reported in Table 5, and those using real measures in Table 6.

These results seem to be more supportive of the modern theory of trade balance than of the standard J-curve hypothesis. First, we found strong evidence ( $\lambda$ is significantly negative) suggesting that changes in the (nominal or real) trade balance Granger-cause changes in the (nominal or real) exchange rate. Thus, the accommodative role of the exchange rate proposed by the modern theory of trade-balance determination has received support from our results. The results obtained provide no support for the presence of a J-curve in China's trade balance, since no evidence of a causal influence from the exchange rate to the trade balance was found. This finding is somewhat consistent with Brada, Kutan and Zhou (1993) 
that the J-curve effect did not appear in China's trade balance following a devaluation in the short run. A tentative explanation for this result may lie in the weak effects of exchange rate on the quantity side of the trade balance. There is no evidence of the presence of Grangercausality from exchange rate to the volumes of imports and exports. Their causal relationship is unidirectional, only from the import and export volumes to the exchange rate. To move a step further we performed some additional causality tests for the prices and the volumes of imports and exports since exchange rate affects the volumes through the prices. Not surprisingly we found no causal effect running from the price variables to the volumes of imports and exports but the opposite relationships held. This finding confirms our belief that prices are not yet the key factor in China's foreign trade management. This seems to be consistent with the causal observation of China's foreign trade behaviour under which the planners set the targeted volumes of imports and exports without much caring about the fluctuations of prices. Even though the foreign trade reform has brought down the proportion of the planned trade, about half of China's imports and exports were still under the direct control or the administrative control in the early 1990s. This portion of the foreign trade is less responsive to changes in import or export prices due to the administrative restraints.

On the other hand, it is interesting to note that a strong bidirectional causal link from the real exchange rate to the price components of trade balance was found, implying that exchange rate of the RMB is causally related to the movements of the prices. This finding seems to be supportive to the argument that the devaluation of the Chinese currency is rather inflationary, and may not improve exports. ${ }^{8}$ It partially explains why in the past China has been very cautiously to devalue its highly over-valued currency, especially when China was facing a high inflation. Our empirical results indicate that, although China has achieved a

\footnotetext{
${ }^{8}$ See Hsu (1989) for instance.
} 
great success with its economic reform program, its foreign trade management and the price system are still not yet market-oriented. Such systems would undoubtedly hamper the adjustment and the responsiveness of its balance of trade to changes in exchange rate policy as well as the pace to integrating the economy into the world financial market.

Table 5: Results of the Bivariate Granger-Causality Tests for the Exchange Rate and the Trade Balance in Nominal Measures

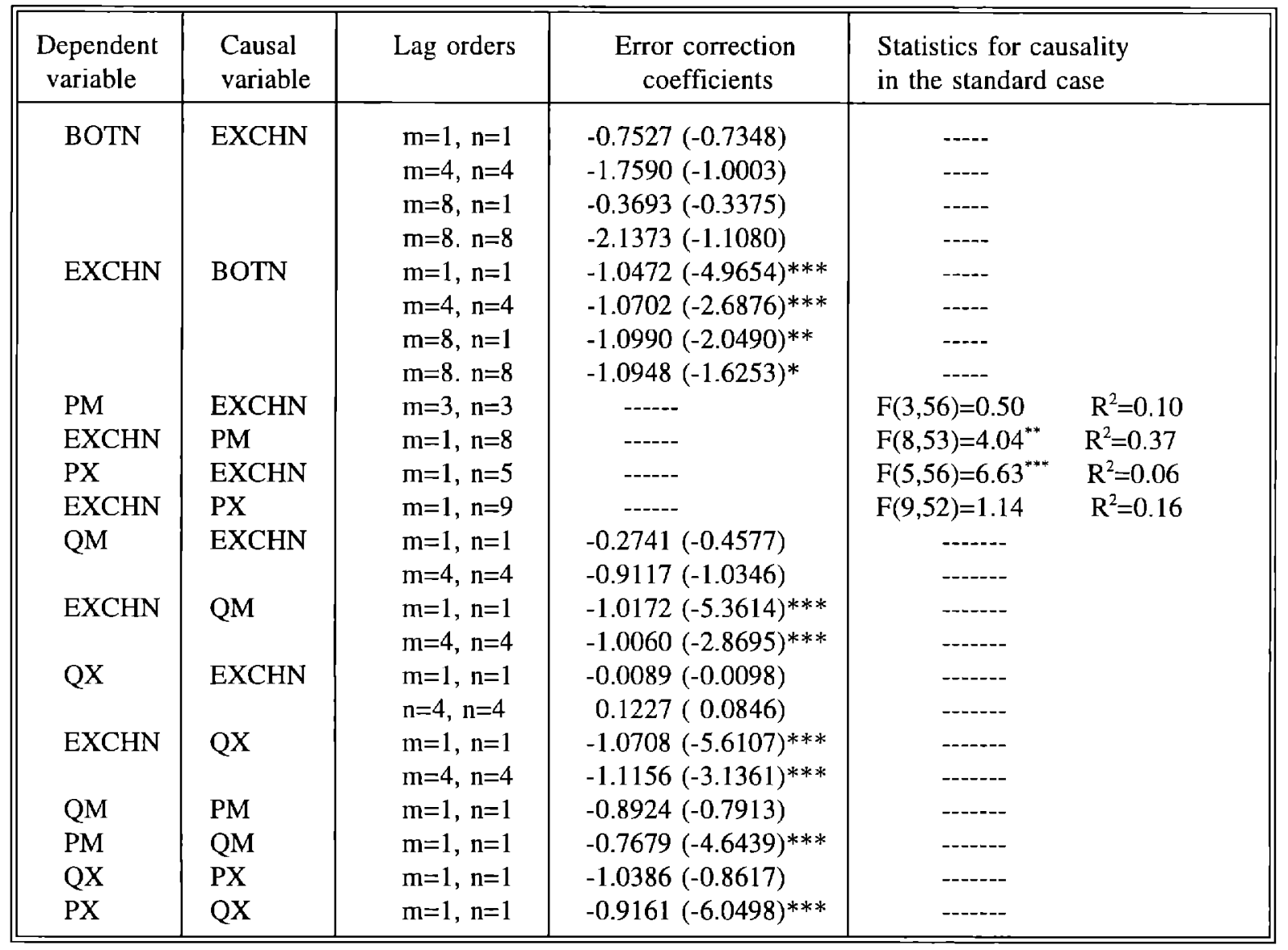

Note: The $t$-statistics are in the parentheses, $* * *$ means significant at the 1 percent level; $* *$ significant at the 5 percent level; and * significant at the 10 percent level. 
Table 6: Results of the Bivariate Granger-Causality Tests for the Exchange Rate and the Trade Balance in Real Measures

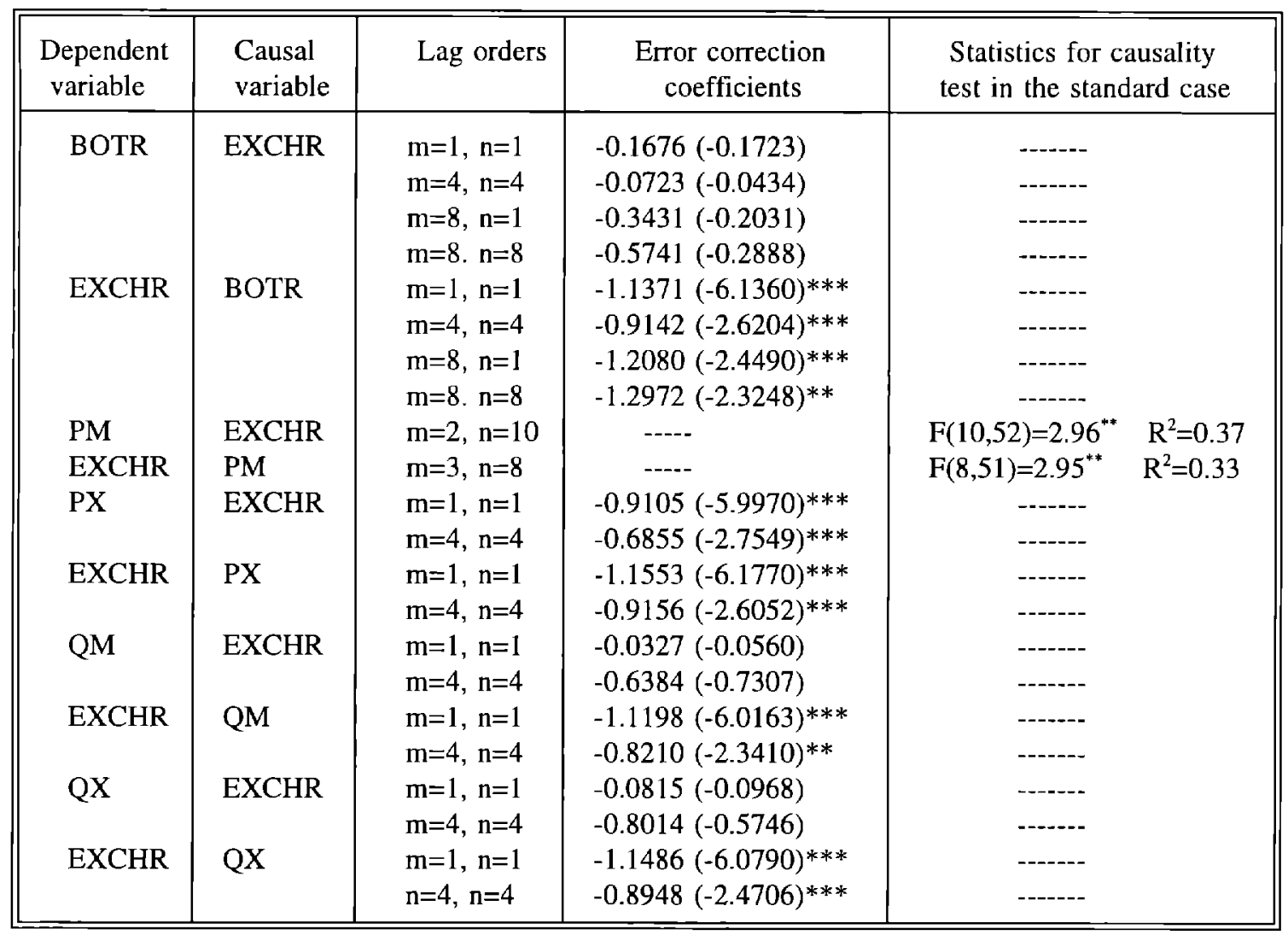

Note: The $t$-statistics are in the parentheses. *** means significant at the 1 percent level; ** significant at the 5 percent level; and * significant at the 10 percent level.

\section{Concluding Remarks}

This paper focuses on the dynamic relationships between the exchange rate of the RMB and China's trade balance and its price and quantity components over the period 1991:M01-1996:M02, apparently an era of more flexible exchange arrangement in China. For this purpose we applied the Engle-Granger method and the Johansen procedures to test for cointegration and the Granger techniques to identify the causal relationship between variables 
of interest.

Our results seem to be rather supportive to the accommodative role of the exchange rate proposed by the modern theory of the trade balance determination as emphasized by the strong causal links running from the trade balance and each of its components to the exchange rate. We did not find evidence suggesting that changes in the (nominal and real) exchange rate Granger-cause changes in trade balance and its quantity components. The absence of a J-curve in China's trade balance is supported by the causally unidirectional relation between the prices and the volumes of imports and exports. This result is consistent with Brada, Kutan and Zhou (1993) that in the short run the J-curve does not appear. Our findings imply that, although China has achieved a great success with its economic reform program, its foreign trade management and prices system are still not yet market-oriented. Such systems would undoubtedly hamper the adjustment and the responsiveness of its balance of trade to changes in exchange rate policy as well as the pace to integrating the economy into the world financial market.

Our findings of a bidirectional causal relationship between the movements in the real exchange rate and the prices variables confirm the presence of a vicious circle hypothesis, implying that the devaluation of the Chinese currency sets in motion inflationary effect on the prices which in turn cause further devaluation of the currency. This partially explains why in the past the Chinese government has been very cautiously to devalue its highly over-valued currency. Our results also suggest that the changes in exchange rate are much a consequence as a cause of trade movements. Changes in the exchange rate of the RMB alone seem less likely improve the trade balance. Under the current economic system, an RMB devaluation can improve China's trade balance only if it is accompanied by other policies. 


\section{References}

Bell, M.W., H.E. Khor and K. Kochhar (1993), China at the Threshold of a Market Economy, IMF: Wahsington DC.

Brada, C.J., A. Kutan and S. Zhou (1993), "China's Exchange Rate and the Balance of Trade", Economics of Planning, vol. 26, pp.229-242.

Dickey, D.A. and Fuller, W.A. (1981), "Likelihood Ratio Statistics for Autoregressive Time Series with a Unit Root", Econometrica, vol 49, pp. 1057-1072.

Engle, R.F. and C.A.J. Granger (1987), "Co-integration and Error Correction: Representation, Estimation and Testing", Econometrica, vol. 55, pp.251-276.

Engle, R.F. and B.S. Yoo (1987), "Forecasting and testing in Cointegrated Systems", Journal of Econometrics, vol. 35, pp.143-159.

Engle, R.F. and C.A.J. Granger (1987), "Co-integration and Error Correction: Representation, Estimation and Testing", Econometrica, vol. 55, pp.251-276.

Granger, C.W.J. (1969), "Investigating Causal Relations by Econometric Models and CrossSpectral Method", Econometrica, vol. 37, pp.462-438.

Granger, C.W.J. (1986), "Developments in the Study of Cointegrated Variables", Oxford Bulletin of Economics and Statistics, vol. 48, pp.213-227.

Greenwood, J. (1984), "Non-traded Goods, the Trade Balance and the Balance of Payments", Canadian Joumal of Economics, vol. 17, pp.806-823.

Gruen D.W. and J. Wilkinson (1994), "Australia's Real Exchange Rate-Is it explained by the terms of Trade or by Real Interest Differentials?", The Economic Record, vol. 70, pp.204-219.

Himarios, D. (1989), "Do Devaluations Improve the Trade Balance? The Evidence Revisited", 
Economic Inquiry, vol. 27, pp.143-168.

Hsu, C.J. (1989), China's Foreign Trade Reforms, USA: Cambridge University Press.

Johansen, S. (1988), "Statistical Analysis of Cointegration Vectors", Journal of Economic Dynamics and Control, vol. 12, pp. 231-254.

Johansen, S. (1992), "Determination of Cointegration Rank in the Presence of a Linear Trend", Oxford Bulletin of Economics and Statistics, vol. 54, pp. 383-397.

Johansen, S. and K. Juselius (1990), "Maximum Likelihood Estimation and Inference on Cointegration with Applications to the Demand for Money", Oxford Bulletin of Economics and Statistics, vol. 52, pp. 169-210.

Mahdavi, S. and A. Sohrabian (1993), "The Exchange Value of the Dollar and the U.S. Trade Balance: An Empirical Investigation Based on Cointegration and Granger Causality Tests", Quarterly Review of Economics and Finance, vol. 33, pp.343-358.

McKinnon, R.I. and K. Ohno (1986). "Getting the Exchange Rate Right: Insulars versus Open Economies", Papers and Proceedings of the 99th Annual Meeting of the Economic Association, New Orleans, (December), pp.22-30.

Mead, E.E. (1988), "Exchange Rates, Adjustment and the J-curve", Federal Reserve Bulletin, (October), pp.633-644.

Miller, S.M. and F.S. Russek (1990), "Co-Integration and Error-Correction Models: The Temporal Causality between Government Taxes and Spending", Southern Economic Journal, pp. 221-229.

Razin, A (1984), "Capital Movements, Intersectoral Resource Shifts, and the Trade Balance", European Economic Review, vol.26, pp.135-152.

Rose, A.K. and J.L. Yellen (1989), "Is There a J-Curve?", Journal of Monetary Economics, vol. 2 , pp.53-68. 
Rosensweig, J.A. and P.D. Koch (1988), "The U.S. Dollar and the Delayed J-Curve", Economic Review, (July-August), pp.2-15.

Wang, H. (1993), China's Exports Since 1979, NY: St. Martin's Press.

World Bank (1990), China: Between Plan and Market, Washington: World Bank.

Zhang, Z.Y.(1995), "China's Foreign Trade Reform and Export Performance", mimeo, National University of Singapore. 